\title{
Alien Plants in the Great Basin ${ }^{1}$
}

\section{JAMES A. YOUNG, RAYMOND A. EVANS, AND J. MAJOR}

Range Scientists, Plant Science Research Division, Agricultural Research Service, U.S. Department of Agriculture, Reno, Nevada; and Ecologist, Botany Department, University of California, Davis, California.

\section{Highlight}

Plant communities in the Great Basin are highly susceptible to invasion by hosts of alien annual species. Highly competitive native annuals did not evolve in the Great Basin to occupy a low seral situation created by intensive grazing. The introduced annual species have been the shadows of domestic livestock since the beginning of agriculture. The alien annuals have highly developed breeding systems which permit adaptation to changing environments.

${ }^{1}$ Received June 14, 1971. Cooperative investigation of the Plant Science Research Division, Agricultural Research Service, U. S. Department of Agriculture and the Agricultural Experiment Station, University of Nevada, Reno, Nevada. Journal Series No. 193. Paper was presented at the 1971 Annual Meeting of the Society for Range Management, Reno, Nevada.
Invasion of alien annual plant species influences all phases of wildland research in the Great Basin. Similar invasions by the same or similar species have occurred in many other parts of the New World. However, the relative impoverished flora of many plant communities of the Great Basin makes it simpler to ascertain the impact of aliens. Our purpose in this review is to bring perspective to the biological importance of this invasion. ${ }^{2}$

${ }^{2}$ In order to maintain continuity to the flow of ideas being presented, we deleted literature citations except for those which introduced the concepts being presented. We realize that many contributions to the literature are not included.
The extent and character of the sagebrush association in pristine condition will probably never be known accurately (Ellison, 1960).

It appears that native plant communities within the big sagebrush/ bunchgrass vegetation type are extraordinarily subject to invasion by alien annual species (Jardine and Anderson, 1919).

Piemeisel (1951) concluded that alien weeds in big sagebrush ( $A$. tridentata Nutt.) communities are largely limited to entering voids in the native vegetation. Apparently, no highly competitive, native annual species have evolved to play a successional role in the low serial situations in these communities. The number of individual native annual species occurring in these communities can be quite large, but rarely if ever, do native annuals dominate low seral communities in this vegetation type. In studies of the big sagebrush/ bunchgrass vegetation of an un- 
grazed kipuka ${ }^{3}$ in southern Idaho, 6 shrubs, 7 grasses, and 10 forbs were mentioned but the only annual was the alien, downy brome (Bromus tectorum L.) (Tisdale et al., 1965). In the description of a near pristine area in central Oregon, Driscoll (1964) recorded nine annuals of which three were aliens. The native annuals such as Orthocarpus tenuifolius (Pursh) Benth., Cryptantha ambigua (Gray) Greene, Lieanthus harkessii (Curran) Greene, and six weeks fescue (Festuca octoflora Walt.) were present, but represented only a minor portion of this community. These, and all other available descriptions, show that native annual species are not abundant in undisturbed big sagebrush vegetation either quantitatively or qualitatively.

\section{Successional Patterns}

In one century big sagebrush communities have known three conditions: pristine; unlimited exploitation by grazing and fire; and attempted complete suppression of fire and attrition by grazing as stand renewal processes.

\section{Pristine Succession}

Before the settlement by Europcan man of western North America, big sagebrush was undoubtedly periodically destroyed in wildfires (Stewart, 1963) or defoliated by larvae of the moth Aroga websteri, but the perennial grass portion of the native communities probably benefitted from the reduced competition (Blaisdell, 1953). Piemeisel (1951) observed that in remote areas where seeds of alien species have not been carried by man's activities, bare or poorly occupied soil is eventually taken over by native perennial species without a seral state dominated by annuals.

The dominant native herbaceous seral species in big sagebrush/ bunchgrass communities are shortlived perennial grasses such as squirreltail (Sitanion hystrix (Nutt.)

\footnotetext{
${ }^{3} \mathrm{Kipuka-old} \mathrm{land} \mathrm{surface} \mathrm{surrounded}$ by recent lava flows, in this case iso-
} lated from grazing.
J. G. Sm.), and Sandberg bluegrass (Poe secunda Presl.) (Piemeisel, 1945; Daubenmire, 1940; Hironaka and Tisdale, 1963). In conjunction with short-lived perennial grasses the native root sprouting shrubs (Chrysothanmus nauseosus (Pall.) Britton, C. viscidiflorus (Hook) Nutt., Tetradymia canescens DC., Prunus andersonii Gray, and Gutierrezia sarothrae (Pursh) Britton and Rusby) colonize burned big sagebrush communities (McKell and Chilcote, 1957). Some species of these shrubs persist in areas of recurring natural disturbances such as active dunes, washouts, and talus slopes. These native short-lived perennial grasses and root-sprouting shrubs must be very effective competitors in their successional situations because no alien species of this growth habit has become established over appreciable areas in big sagebrush/bunchgrass vegetation. C. viscidiflorus is also sufficiently competitive to invade dense downy brome stands. This native shrub can also invade stands of the alien, but desirablc, and, thcrefore, widely planted perennial crested wheatgrass (Agropyron desertorum (Fisch. ex Link) Schult.) which, once established, can suppress downy brome (Tueller and Evans, 1961).

\section{Modern Succession}

The rapid and continued turnabouts in stand renewal process have created a vegetation of excess in much of western North America. Especially, the disturbed big sagebrush communities have not been able to equilibrate under any one stand renewal process.

A complicating factor in understanding current successional patterns in big sagebrush communities is that the density of big sagebrush has greatly increased on over-grazed ranges (Stoddart, 1941). This increase has largely been at the expense of perennial grasses. Depleted big sagebrush stands with virtually no understory are not vulnerable to wildlife except under conditions of extreme fire hazard. It is dif- ficult to get the fire to spread from shrub to shrub with no understory. If the depleted communities burn and grazing pressure is relaxed, succession can proceed to perennial grass domination (Blaisdell, 1953). A much more typical situation involves an increase in herbaceous alien annuals beneath the big sagebrush overstory. This type of community is closed to invasion by desirable perennials (Robertson and Pearce, 1945). During years of more than average spring precipitation these communities are extremely susceptible to wildfires. Adaptation to repeated burning is a characteristic which is shared by the majority of the aliens. Burning can be used as a control measure for alien annual grasses if it is properly timed (McKell et al., 1962). However the aliens are admirably adapted to escaping seed destruction by most wildfires. Kearney et al. (1914) described the succession on burned sagebrush-grass communities as follows:

"The fire consumes the dry herbaceous growth and the sagebrush plants are usually burned to the ground. They do not sprout up from the old stumps, and the result is usually the complete removal of the Artemisia. In the following year a mat of herbaceous vegetation composed chiefly of cheatgrass (downy brome) and redstem filaree (Erodium cicutarium (L.) L'Her.) covers the ground among the blackened stumps."

Although consuming the woody portions of the community, wildfires usually occur after the annual grasscs mature and their seeds have dropped to the ground, while the seeds of the native perennial grasses and herbs are still attached to the plant (Warg, 1938). Cottam and Evans (1945) attributed the prominencc of downy brome in an area ungrazed for at least 40 years to frequent fires.

Fire undoubtedly burned in pristine big sagebrush communities both from natural occurrence and as a function in the ecosystems of the endemic aborigines (Stewart, 1963). A tremendous increase in 
accidental and intentional wildfires accompanied European man's settlement of the Intermountain Region. The fuel provided by early maturing, highly flammable alien annuals contributed to the incidence and spread of these species.

\section{Seral Continuum}

A characteristic which adds cohesiveness to the alien species is their occurrence in a seral continuum. Piemeisel (1932 and 1938) clearly enumerated the succession of Russian thistle (Salsola kali var. tenuifolia Tausch) to tumble mustard (Sisymbrium altissimum L.) or tansy mustard (Descurainia pinnata (Walt.) Britton) to downy brome on abandoned fields cleared from big sagebrush. Succession in the broadleaf portion of the seral continuum was largely ignored until Evans et al. (1967) reported the removal of the dominant alien grass with herbicides allowed expression of the broadleaf successional species. In effect, the seral continuum allows continued occupancy of the site by the aliens over a broad spectrum of disturbance pressure. Release the pressure and succession will proceed to a downy brome community. Increase the disturbance pressure and succession will regress to a Russian thistle community but each community offers severe competition to seedlings of native or introduced perennial grasses.

It is possible to add new dimensions at either end of the seral continuum as in the case of halogeton (Halogeton glomeratus (Bieb.) C. A. Mey.) at the bottom or medusahead (Taenia therum asperum (Sim.) Nevski) at the top.

Within the genera of both the weedy grasses (Bromus and Taeniatherum), and forbs (Erodium, Sisymbrium, Descurainia, Salsola, and Lepidium) a number of species were differentiated which have largely remained restricted to Central Asia or to the Old World Mediterranean arca or to both. We always have the possibility of introducing one of these species to the Great Basin.

\section{Changing Livestock Pattern}

Big sagebrush communities in western North America have been subjected to attrition by grazing of domestic livestock for the past century. The range livestock industry has undergone radical changes over that period of time and these changes influence the stand renewal process in the grazed communities. The abundance of the various classes of livestock grazed has changed during the century. The decline in numbers of range sheep and horses in Nevada reflects the trend in all of western North America. Feral horse herds became so large at the turn of the century it was necessary to destroy or trap and ship to market great numbers of animals (McKnight, 1964). Today the feral horses must be protected to save them from "extinction." Wintering of horses on the range kept grazing pressurc on the native plant communities during the season when cattle and sheep received supplemental feeding on ranches.

Close herding of range sheep from established bed-grounds virtually eliminated all vegetation in some areas (Fleming, 1922). The range sheep industry has undergone a period of decline and improved open herding methods have greatly reduced this destruction. Griffiths (1902) considered indiscriminate grazing by migratory sheep bands whose owners had no commensurate property to be the prime factor in the destruction of big sagebrush communities in the Great Basin. The migratory bands provided a means of dispersal for seeds of aliens as well as creating low seral environments.

\section{Stand Renewal by Range Improvement}

The application of range improvement practices to vast areas of big sagebrush has introduced a new type of stand renewal process. The use of esters of (2,4-dichlorophenoxy) acetic acid (2,4-D) makes it possible to remove the shrub overstory without resorting to fire (Hull and Vaughn, 1951). However, the success of this technique is dependent on how many remnant perennial grasses are left in the understory (Hyder, 1954). Removing the shrubs by spraying 2,4-D can result in domination of the site by aliens just as in the case of wildfires.

Establishment of desirable wheatgrasses in big sagebrush communities is the only range improvement possibility when the perennial understory is too depleted to benefit from spraying the brush. If these seedlings fail to establish, annual domination results just as surely as it did on abandoned farmlands in the 1930's.

\section{Origin of Competitive Aliens}

The importance of aliens as weeds in western North America has long been recognized. However, the true origin of the aliens which dominate the big sagebrush/ bunchgrass seral communities is somewhat obscure. The major grasses and the broadleaf species have been broadly categorized by American authors as Mediterranean in origin. These species have a wide distribution in the heavily grazed portions of the Mediterranean basin but they are also found as aliens in areas of South America and Australia with similar climates and intensive grazing.

The only other area of the world with vegetation similar to the big sagebrush/bunchgrass type of western North America is the Artemisia steppe of central Asia (Mirov, 1951). The highly competitive annual species which now play such a dominant role in the succession of big sagebrush communities in the Great Basin fulfill the same role in central Asia.

The annual colonizing species may have originated elsewhere, but they found conditions in central Asia conducive to the selection of highly competitive genotypes. The Artemisia steppe of Asia has been subjected to centuries of intensive 
grazing by a wide spectrum of herbivores. Soon after the beginnings of agricultural cultures in the region from India to the Mediterranean, domestic livestock spread into the steppes of Eurasia (Sauet, 1956).

In central Asia agriculture became pastoral with nomadism. The movements of nomadic tribes and the restricted distribution of potable or stock water produced concentrations of grazing livestock which tended to create and maintain low seral plant communities. Kubanskaja (1956) could identify the ancient migratory routes in the Bet-Pak-Dala desert of the "people who are no more," by the predominance of weedy annuals.

Flannery (1969) likens the development of agriculture to another example of second cybernetics. Starting with a relativcly stable configuration of plant and animal species about 10,000 B.C., early cultivation took two genera of seral grasses and two genera of small ungulates out of their habitat and artificially increased their numbers while they underwent a series of genetic changes, many of which were favorable in terms of compatability with man. These favorable changes made feasible a still greater investment of human labor in agriculturc and a greater artificial expansion of some species at the expense of species not adaptable to man's influence. At this point, the ecosystem was no longer in a cybernetic state; all former rules which had controlled succession were lost.

If the domestication of plants and animals were man's foredrop to civilization, then the alien annual weeds of grazing lands are the shadow of civilization. The development of concentration of domestic herbivores created the low seral situations and forced selections of species to fill these vacant niches.

The gregarious herbivores of Eurasia largely escaped extinction at the end of the Pleistocene by domestication. In the Great Basin, there was no escape and the large herbivores became extinct or with-
Therefore, for about 10,000 years prior to the introduction of domestic livestock, there were no requirements for plant species to grow in seral habitats created and maintained by grazing.

\section{Competitive Characteristics}

The introduced annual weeds of big sagebrush communities and especially downy brome have frequently been rated as vigorous competitors (Hull, 1944). Pickford (1932) reported downy brome made up less than $1 \%$ of the natural vegetation of ungrazed and unburned ranges. Where disturbance had created voids in perennial big sagebrush communities, Stewart and Hull (1949) counted 1,080 to 15,000 downy brome seedlings per $\mathrm{m}^{2}$. What contrasting populations from less than $1 \%$ of undisturbed native communities to complete dominance of seral communities. Which successional situation most fully characterized the inherent competitive potential of the alien annuals?

Investigation has shown that seeding perennial grasses into annual dominated communities most often ends in failure unless some means is employed to reduce competition (Platt and Jackman, 1946).

In controlled greenhouse experiments, Evans (1961) demonstrated that downy brome at 690 and 2,760 plants per $\mathrm{m}^{2}$ severely curtailed shoot and root growth and greatly increased mortality of crested wheatgrass seedlings.

In southeastern Washington, Daubenmire (1940) and Harris (1967) observed that downy brome has inserted itself successfully into climax bunchgrass stands that have been protected from grazing or fire for as long as 50 years. For how many ycars had native vegetation at these sites evolved toward an equilibrium which fully occupied the potential of the environment? Is not the successful establishment of downy brome in these communities the ultimate in competitive ability? Does downy brome compete with the native plant community in equilibrium or do the aliens exist on environmental potential untapped by the native species?

During the past 50 years, attempts to replace the alien annual species with native perennial grass species have generally ended in failure despite the eloquent pleas by Kennedy (1903) that the natives reflect inherently perfect adaptation to the local environment. Millions of acres have been revegetated with perennial wheatgrass from central Asia (Love and Hansen, 1932). How many seasons did these alien wheatgrasses complete with the alien annuals in their native habitats before they were both introduced into North America?

We may ask, is intensive pressure by man and his grazing animals necessary to evolve competitive annual colonizers?

\section{Nature of Competitive Ability}

During the past 35 years, range scientists have gradually comprehended the magnitude of the inherent competitive ability of alien annuals. A series of investigations has been conducted to determine the characteristic which allows the alien weeds to compete so successfully (see Klemmedson and Smith (1964) for many of these studies). These investigations have shown dramatic advantages for the alien species, but fail to show any single overriding competitive advantage shared by all the aliens.

In virtually undisturbed big sagebrush communities in pristinc condition, the perennial species probably did not need to reproduce every year to maintain stand density. Considering the erratic climate of the big sagebrush areas, it is possible that seedlings of many of the perennial species only became established during these irregularly occurring years with above normal precipitation. Harris (1967) found that seedlings of bluebunch wheatgrass (Agropyron spicatum (Pursh) Scribn. and Sm.) survived and became established only in summers with above average precipitation. The aliens must complete their life 
cycle annually so their reproductive ecology must be very efficient. The aliens not only germinate and become established, but they also close the reproductive niches of the native peremnials. To accomplish this, the aliens must have both phenotypic and genotypic plasticity to survive in the below average years and to preempt the environmental potential in the above average seasons (Harper and Gajic, 1961).

\section{Seedbed Characteristics}

The annual habit of the alien species makes their seeds or caryopses the key to their continued occupancy of the site. Unfortunately, a static concept of germination of downy brome and medusahead has become widely accepted (Hulbert, 1955) in the western United States. It has become accepted that seeds of the aliens germinated the year they were produced without a residue of seeds in the soil and litter. Chepil et al. (1946) clearly determined this was not true and recent investigations by Young et al. (1969) have shown how the alien annual species can have the advantages of both simultaneous and continuous germination.

In order to occupy disturbed areas of disjunct distribution, the alien annuals must have highly developed dispersal mechanisms. Except for investigation of the dispersal of downy brome by Hulbert (1955) and Lehrer and Tisdale (1956), little is known of dispersal mechanisms of the aliens.

Following Piemeisel's (1951) scheme of succession in low seral communities on big sagebrush sites, there is a strong relation between reproductive potential, dispersal mechanisms, and seral level. The lowest seral species, Russian thistle and halogeton, produce a great many very small seeds and have advanced dispersal mechanisms to shower surrounding areas with their seeds. The annual grasses which occupy a higher seral position produce fewer, but much larger caryopses. Harper et al. (1965) stressed the physical characteristics of the seedbed as the factor determining population size and species composition of colonizing communities. Evans and Young (1970) have equated population size of specific species of alien annuals to individual parameters of the microenvironment of the seedbed (i.e. air and soil temperature and soil moisture) which, in turn are manifested by specific conditions of the seedbed (i.e. litter coverage, microtopography, and soil texture). Litter accumulation is directly related to seral stage of the plant community in that germination and establishment of the higher successional species (downy brome and medusahead) require environmental conditions less harsh than those of bare soil. Lower successional species (Russian thistle and tumble mustard) can become established on bare soil.

Differences in safe site requirements for establishment among species are, in part, due to physical characteristics of the seed or caryopses. Seed size, specific gravity, and character of the seed coat are all important in relation to the microscale of the seedbed and its providing a suitable environment for one species and not another. Because there is succession among annual species, competition for safe sites and the varying efficiency in the germination process among species must also be a vital dynamic operative in these communities.

\section{Breeding Systems}

The most conspicuously successful alien annuals are predominately self-pollinated. Analyses of the genetic systems of certain of the most successful alien colonizing species of the annual ranges of California indicate that these systems represent a compromise between the high recombinational potential of out-breeding species and the stability traditionally postulated for selfpollinated species (Stebbins, 1957). These species appear to bc capable of adjusting their genetic systems to obtain variability rapidly by virtue of ready modification of levels of out-crossing, crossover rates, and other factors which govern recombination rates. Allard (1965) postulates that successful colonizers have genetic systems optimum both for opportunistic settlement and enduring occupation of diverse and complex habitats.

Investigations of the variability within and among selections of downy brome and medusahead from a variety of habitats have shown significant variability for a number of characteristics important to the establishment and reproduction of alien species (Hulbert, 1955; McKell et al., 1962; Young et al., 1970).

Stebbins (1957) in his review of the genetics of successful selfpollinating species stated:

\begin{abstract}
"Each successful biotype maintains itself a constant, genetically homozygous pureline for a large number of generations and is represented by hundreds or thousands of individuals. It is normally isolated by selffertilization from other biotypes of the same species with which it grows sympatrically. Occasionally, however, accidental crossing between biotypes may take place..."
\end{abstract}

Stebbins indicated the majority of the recombinations are more poorly adapted than the parental types, but a few form the progenitors of new lines.

In genera of which the phylogenetics of species have been studied (i.e. Bromus) (Stebbins, 1957), the self-fertilized species appear to be more specialized in morphological characteristics than many of their cross fertilized relatives. A very high proportion of them have annual life cycles (Stebbins, 1950), a condition which is generally regarded by morphologists to be derived from the perennial growth habit.

To explain the presence of flower structures which are associated with cross fertilization in self-fertilized species, Stebbins (1957) cites the principle that the origination of elaborate structures, which depends on the interaction of a complex 
combination of genetic factors, requires much stronger selective pressures than their maintenance once they have originated. Can this same principle be applied to the complex of morphologic and physiologic characteristics which make alien annuals so competitive? Do genera such as $A$ gropyron lack basic genomes, present in Bromus, permitting the selection of ecotypes which are highly competitive under intensive grazing in big sagebrush vegetation? The noxious alien annual, Exempyrum triticeum (Gaertn.) Nevski (Agropyron triticeum Gaertn.), has been introduced to western North America, but is relatively rare in comparison to downy brome.

Both Stebbins and Allard relegate crossing between largely selfpollinated individuals to accidental occurrences. However, Stcbbins (1957) reviews work of Harlan (1945) which suggested that flower parts governing cross fertilization can respond to changing environmental conditions. Conditions favorable for cross pollination might be absent altogether in climates as highly variable as those in the Intermountain area. Self-fertilization insures fertility in plants subject to periodic droughts and isolated dispersal (Baker, 1955). Do periodic pcriods of environmental abundance condition cross fertilization? This may be the crucial point in understanding the significance of the genetics of alien species in big sagebrush communities. If the amount of crossing among individuals is a function of the environmental conditions in which the annuals are growing, their breeding system could assume great ecological significance. The reproductive potential of downy brome in terms of number of tillers, panicle spikelets, and florets has shown to be density dependent (Hulbert, 1955; Young et al., 1969). Reduced density results in great increases in caryopses production per plant. Do lodicule turgidity, anther exertion, pollen vitality, and stigma exertion and receptivity also respond $\mathrm{dy}$ - namically to increased environmental potential per individual?

The invasion of medusahead in sagebrush communities on the margin of the Great Basin is accomplished by disjunct introductions which can remain isolated for many generations. These isolated populations may remain very restricted and stable for years before suitable environmental conditions permit rapid invasion and domination of surrounding communities (Young and Evans, 1970).

What is the breeding system of medusahead during these sudden expansions in range? Could there be sufficient hybridization for a population expression of heterosis? Isolated introductions of one or a few propagules necessitates a restricted gene pool (Harper, 1965). Each generation, the individuals of isolated stands, represent opportunity for selection in the inbreeding populations under the local environmental conditions. What happens when two or more long isolated populations merge in a favorable environment?

If heterosis is a factor in the sudden spread of alien annuals there must also be periods of recline in vigor as populations segregate, but the aliens are the seral species and "weeds cannot maintain constant population sizes" (Stebbins, 1950). Numerical increases with diversity prepared the way for numerical decline with uniformity (Ford, 1964).

\section{Biological Vacuum}

After the introduction of domestic livestock, there was a considerable lag until alien plant species became abundant. By the turn of the century, alien annuals were absent or extremely rare in northeastern Nevada (Kennedy, 1903) and downy brome had not been introduced to western Nevada (Kennedy and Doten, 1901). A great deal of low seral habitat was prepared and available for the establishment of aliens. The annuals were introduced into a biological near-vacuum (McKell et al., 1962).
The period of greatly reduced competition allowed the perpetuation of many of the new genotypes that were created by hybridization and recombination. These genotypes may not have a clear competitive advantage in their present habitat (Young et al., 1970) but given the chance of dispersal the inherent variability insures dominance in a variety of environments.

Presence of these alien annual species on rangelands of the Great Basin truely reflects the effects of past activities of man and his animals. Further, these annual species represents a difficult problem for range managers at present. Only recently have successful methods and techniques been developed to control these species and replace them with higher value, more stable perennial grasses (Evans, et al., 1969).

\section{Literature Cited}

Allard, R. W. 1965. Genetic systems associated with colonizing ability in predominantly self-pollinated species. In H. G. Baker and L. Stebbins (ed.). The Genetics of Colonizing Species. Academic Press, New York. 588 p.

ВаKER, H. G. 1955. Self compatibility and establishment after "Long-distance" dispersal. Evolution 9:347348.

Blaisdell, J. P. 1953. Ecological effects of planncd burning of sagebrush-grass range on the Upper Snake River Plains. U. S. Dep. Agr. Tech. Bull. 1075. 39 p.

ChePIL, W. S. 1946. Germination of weed seeds. I. Longevity, periodicity of germination, and vitality of seeds in cultivated soil. Sci. Agr. 26:307346.

Cottam, W. P., and F. R. Evans. 1945. A comparative study of the vegetation of the grazed and ungrazed canyons of the Wasatch Range, Utah. Ecology 26:171-181.

Daubenmire, R. 1952. Forest vegetation of northern Idaho and adjacent Washington and its bearing on concepts of vegetation classification. Ecol. Monogr. 22:301-330.

Daubenmire, R. 1940. Plant succession due to overgrazing in the Agropyron bunchgrass prairie of southeastern Washington. Ecology 21:55-64. 
Driscoll, R. S. 1964. A relict area in the central Oregon juniper zone. Ecology 45:345-353.

Ellison, L. E. 1960. Influence of grazing on plant succession on rangelands. Bot. Rev. 26:1-78.

Evans, R. A. 1961. Effects of different densities of downy brome (Bromus tectorum L.) on growth and survival of crested wheatgrass (Agropyron desertorum) in the greenhouse. Weeds 9:216-223.

Evans, R. A., R. E. Eckert, JR., AND B. L. KAY. 1967. Wheatgrass establishment with paraquat and tillage on downy brome ranges. Weeds 15 : 50-55.

Evans, R. A., J. A. Young, and R. E. ECKERT, JR. 1969. Herbaceous weed control and revegetation of semiarid rangelands in western United States. Outlook on Agr. 6:60-66.

Evans, R. A., AND J. A. Young. 1970. Plant litter and establishment of alien annual species in rangeland communities. Weed Sci. 18:697-703.

FlanNery, K. V. 1969. Origins and ecological effects of early domestication in Iran and the Near East. p. 73-100. In P. J. Ucko and G. W. Dimbleby (ed.). The Domestication and Exploitation of Plants and Animals. Aldine Pub. Co., Chicago 581 p.

Fleming, C. E. 1922. One-night camps versus established bed-grounds on Nevada sheep ranges. Nev. Agr. Exp. Sta. Bull. 103. 21 p.

Ford, E. B. 1964. Ecological Genetics. John Wiley and Sons, Inc., New York. $320 \mathrm{p}$.

Griffiths, D. 1902. Forage conditions on the northern border of the Great Basin, being a report upon investigations made during July and August, 1901, in the region between Winnemucca, Nevada and Ontario, Oregon. U. S. Bur. Plant Indus. Bull. 38. $52 \mathrm{p}$.

Harlan, J. R. 1945. Cleistogamy and chasmogamy in Bromus carinatus Hook. and Arn. Amer. J. Bot. 32: 66-71.

HARPER, J. R. 1965. Establishment, aggression, and cohabitation in weedy species (ed.). H. G. Baker and G. L. Stebbins. The Genetics of Colonizing Species. Academic Press. New York. 588 p.

Harper, J. L., and D. Gajic. 1961. Experimental studies of the mortality and plasticity of a weed. Weed Res. 1:91-105.
Harper, J. L., J. T. Williams, and G. R. SAGAR. 1965. The behavior of seeds in soil. I. The heterogeneity of soil surfaces and its role in determining the establishment of plants. Ecology 53:273-289.

Harris, G. A. 1967. Some competitive relationships between Agropyron spictatum and Bromus tectorum. Ecol. Monogr. 37:89-111.

Hironaka, M., and E. W. Tisdale. 1963. Secondary succession in annual vegetation in southern Idaho. Ecology 44:810-812.

HulberT, L. C. 1955. Fcological studies of Bromus tectorum and other annual bromegrasses. Ecol. Monogr. 25:181-213.

Hull, A. C., JR. 1944 . Regrassing southern Idaho rangelands. Idaho Ext. Bull. 146. 7 p.

Hull, A. C., JR., and W. T. Vaughn. 1951. Controlling big sagebrush with 2,4-D and other chemicals. J. Range Manage. 4:158-164.

Hyder, D. N. 1954. Spray to control big sagebrush. Oregon State Univ. Agr. Exp. Sta. and U. S. Dep. Interior Bull. 538. 12 p.

JARdine, J. T., AND M. ANDERson. 1919. Range Management on the national forest. U. S. Dep. Agr. Bull. 790. 98 p.

Kearney, T. H., L. J. BRIGgS, AND H. T. Shantz. 1914. Indicator significance of vegetation in Tooele Vallcy, Utah. Agr. Res. 1:365-417.

KenNedy, P. B. 1903. Summer ranges of eastern Nevada. Nev. State Univ., Agr. Exp. Sta. Bull. 55. 53 p.

KenNedy, P. B., AND S. B. Doten. 1901. A preliminary report on the summer ranges of western Nevada sheep. Nev. State Univ., Agr. Exp. Sta. Bull. 51. 54 p.

Klemmedson, J. O., and J. G. Smith. 1964. Cheatgrass (Bromus tectorum L.). Bot. Rev. 30:226-262.

Kubanskaja, Z. V. 1956. The vegetation and fodder resources of the Bet-Pak-Dala Desert. AlmaAta. Acad. Sci. Kazah USSR. 264 p.

Lehrer, W., and E. W. Tisdale. 1956. Effect of shecp and rabbit digestion on the viability of some range plant seeds. J. Range Manage. 9:118-123.

Love, L. D., and H. C. Hanson. 1932. Life history and habits of crested wheatgrass. J. Agr. Res. 45:371-383.

Major, J., C. M. McKell, and L. J. BERRY. 1960. Improvement of medusahead infested rangeland. Calif. Agr. Exp. Sta. Leaf. 123. 3 p.
McKell, C. M., and W. W. Cinllcote. 1957. Response of rabbitbrush following removal of competing vegetation. J. Range Mange. 10:228-230.

McKell, G. M., J. P. Robinson, AND J. MAJOR. 1962. Ecotypic variation in medusahead, an introduced annual grass. Ecology 43:686-698.

McKNIGHT, T. 1964. Feral livestock in Anglo-America. Vol. 16, Univ. of Calif. Pub. in Geography. Univ. of Calif. Press. Berkeley, Calif.

Mirov, N. T. 1951. Geography of Russia. John Wilcy and Sons, New York. $360 \mathrm{p}$.

Pigkford, G. D. 1932. The influence of continued heavy grazing and of promiscuous burning on spring-fall ranges in Utah. Ecology 13:159-171.

Piemeisel, R. L. 1951. Causes affecting change and rate of change in a vegetation of annuals in Idaho. Ecology 32:53-72.

Piemeisel, R. L. 1938 . Changes in weedy plant cover on cleared sagebrush land and their probable causes. U. S. Dep. Agr. Tech. Bull. 654 . $48 \mathrm{p}$.

Piemeisel, R. L. 1945. Natural replacement of weed host of the beet leaf hopper as affected by rodents. U. S. Dep. Agr. Circ. 739. 48 p.

Piemeisel, R. L. 1932 . Weedy abandoned lands and weed hosts of the beet leaf hopper. U. S. Dep. Agr. Circ. 229.

Platt, L., and E. R. Jackman. 1946. The cheatgrass problem in Oregon. Oregon Agr. Ext. Ser. Bull. 668. 32 p.

Robertson, J. H., and G. K. Pearse. 1945. Artificial reseeding and the closed community. Northwest Sci. 19:58-66.

Sauet, C. O. 1956. The agency of man on earth. 19-69 p. In W. L. Thomas, Jr. (ed.). Man's Role in Changing the Face of the Earth. Univ. of Chicago Press. Chicago, Ill. $1188 \mathrm{p}$.

Stebins, G. L., JR. 1957. Self-fertilization and population variability in the higher plants. Amer. Nat. 91: 332-354.

Stebbins, G. L. 1950. Variation and evolution in plants. Columbia Univ. Press. $643 \mathrm{p}$.

Stewart, G., and A. C. Hull. 1949. Cheatgrass (Bromus tectorum L.)An ecologic intruder in southern Idaho. Ecology 30:58-74.

Stewart, O. C. 1963. Barriers to understanding the influence of use of fire by aborigines on vegetation. 
Proc. 2nd Tall Timbers Fire Ecol. Conf., Tallahassee, Fl. p. 117-126.

Stondart, L. A. 1941. The palouse grassland association in northern Utah. Ecology 22:158-163.

Tisdale, E. W., M. Hironaka, and M. A. Fosberg. 1965. An area of pristine vegetation in Craters of the Moon National Monument, Idaho. Ecology 46:349-352.
Tueller, P. T., And R. A. Evans. 1969. Control of green rabbitbrush and big sagebrush with 2,4-D and picloram. Weed Sci. 17:233-235.

Warg, S. A. 1938. Life history and economic studies on Bromus tectorum. Unpub. M.S. Thesis, Univ. Montana, Missoula, Mon. 38 p. As cited in J. O. Klemmedson and J. G. Smith. 1964.
Young, J. A., AND R. A. Evans. 1970. Invasion of medusahead into the Great Basin. Weed Sci. 18:89-97.

Young, J. A., R. A. Evans, and R. E. Eckert, JR. 1969. Population dynamics of downy brome. Weed Sci. 17:20-26.

Young, J. A., R. A. Evans, and B. L. Kay. 1970. Phenology of reproduction of medusahead. Weed Sci. 18: 451-454. 